\title{
ZALEŻNOŚCI POMIĘDZY DOŚWIADCZANYM POZIOMEM BEZPIECZEŃSTWA A AKTYWNOŚCIĄ OBYWATELSKĄ Z UWZGLĘDNIENIEM MODYFIKUJĄCEJ ROLI PŁCI ${ }^{2}$
}

\begin{abstract}
Bezpieczeństwo jest jedną z podstawowych kategorii pozwalających człowiekowi na prawidłowe funkcjonowanie. Może być rozumiane obiektywnie oraz subiektywnie. Prezentowany artykuł odnosi się do subiektywnego, psychologicznego aspektu doświadczania bezpieczeństwa i zakłada, że doświadczanie bezpieczeństwa ma związek z ogólnie rozumianą aktywnością człowieka, a więc także ze specyficznym rodzajem działań - nastawionym na rzecz zadbania o interes społeczny. Artykuł wskazuje na podstawowe zależności między dwiema zmiennymi - doświadczaniem bezpieczeństwem a aktywnością obywatelską i stawia pytania o specyfikę związku, uwzględniając także zróżnicowanie dotyczące płci. Obie zmienne traktowane są jako złożone zjawiska. Doświadczenie bezpieczeństwa składa się $\mathrm{z}$ aspektu emocjonalnego (poczucie bezpieczeństwa) oraz poznawczego (refleksja nad bezpieczeństwem). Aktywność obywatelska zaś opisana jest przez cztery rodzaje działań: społecznikostwo, partycypacja społeczna, indywidualna aktywność polityczna oraz partycypacja polityczna. Model ten opiera się na dwóch kryteriach: obszar zaangażowania oraz sposób odniesienia do innych ludzi. Badania empiryczne przeprowadzono na grupie 314 osób z zastosowaniem autorskich narzędzi Skali Doświadczanego Bezpieczeństwa (SDB) oraz Kwestionariusza Aktywności Obywatelskiej (KAO). Uzyskane wyniki wskazują, że zakładana zależność istnieje, choć nie jest wysoka, i dotyczy właściwie aktywności realizowanej indywidualnie (działania wspólnotowe nie wiążą się z kontekstem doświadczania bezpieczeństwa). Płeć stanowi czynnik różnicujący badaną podstawową zależność w taki sposób, że dla mężczyzn w wyjaśnianiu aktywności obywatelskiej większe znaczenie odgrywa refleksja nad bezpieczeństwem, dla kobiet zaś istotne jest poczucie bezpieczeństwa oraz refleksja nad nim.

Słowa kluczowe: rodzaje aktywności obywatelskiej, doświadczanie bezpieczeństwa, poczucie bezpieczeństwa, refleksja nad bezpieczeństwem, różnice międzypłciowe
\end{abstract}

\section{WPROWADZENIE TEORETYCZNE}

\subsection{Aktywność obywatelska}

Podstawą istnienia społeczeństwa obywatelskiego jest działalność jego członków na rzecz interesu społecznego, rozumiana jako aktywność obywatelska. Można ją zdefiniować jako aktywność społeczną jednostek będącą wynikiem indywidualnych motywów lub oddolnych inicjatyw społecznych, nastawioną na realizację szeroko

\footnotetext{
${ }^{1}$ Dr Ryszard Klamut, Zakład Nauk Humanistycznych, Wydział Zarządzania, Politechnika Rzeszowska, e-mail: rklamut@prz.edu.pl

${ }^{2}$ Dziękuję osobom, które pomogły w zbieraniu danych: Marioli Łagunie, Piotrowi Próchniakowi, Wiktorowi Razmusowi, Kindze Wywrot, Krzysztofowi Surowcowi.
} 
rozumianego wspólnego dobra ${ }^{3}$. Jej celem jest poszerzanie zakresu działań organizowanych przez obywateli, poprawa stylu i jakości ich życia, a także wywieranie wpływu na instytucje państwowe i samorządowe. Działania na rzecz społeczności podnoszą także możliwość osiagania interesu własnego - zaspokajania własnych potrzeb i zainteresowań, a także zadbania o własne bezpieczeństwo. Ten rodzaj aktywności jest wynikiem społecznej kondycji człowieka jako istoty społecznej. Z jednej strony człowiek czuje się zobowiązany do działania na rzecz grupy i realizacji norm grupowych, z drugiej zaś przynależność do społeczności przynosi mu korzyści ${ }^{4}$.

Aktywność obywatelska jest szerokim i niejednorodnym zbiorem działań, które są różnie klasyfikowane, na bazie przyjętych kategorii treściowych lub formalnych ${ }^{5}$. Te wszystkie działania można pogrupować w cztery kategorie na podstawie dwóch formalnych kryteriów, jakie stanowią obszar zaangażowania oraz zależność/niezależność od grupy. Działania mogą być podejmowane indywidualnie bądź zespołowo (wspólnotowo). Moga jednocześnie dotyczyć kwestii pomocy innym (służba) lub też chęci wywierania wpływu (władza). Służba bazuje na prospołeczności, władza zaś to obszar aktywności politycznej ${ }^{6}$. Uwzględniając jednocześnie oba kryteria Klamut ${ }^{7}$ wyróżnił cztery rodzaje aktywności: społecznikostwo, partycypacja społeczna, indywidualna aktywność polityczna oraz partycypacja polityczna. Społecznikostwo to zespół indywidualnych działań nastawionych na pomoc innym, partycypacja społeczna nastawiona jest także na poprawę jakości życia i pomoc osobom potrzebującym, ale podejmowana przez osoby działające w ramach organizacji. Indywidualna aktywność polityczna obejmuje różne działania skoncentrowane na wywieraniu wpływu na instytucje sprawujące władzę, zaczynając od działań służących lepszemu rozumieniu rzeczywistości społeczno-politycznej, przez zabieranie głosu w istotnych społecznie sprawach do udziału w demonstracjach i świadomym wyborze kandydatów do pełnienia stanowisk politycznych. Partycypacja polityczna odnosi się zaś do aktywności w ramach grup, stowarzyszeń, partii politycznych w wyborach politycznych i stanowieniu prawa służącego obywatelom.

Najczęściej aktywność obywatelska badana jest jako ogólny poziom aktywności, lub też liczba działań podejmowanych przez ludzi. Tak badaną aktywność obywatelską traktuje się jako kontinuum od niskiego do wysokiego poziomu zaangażowania w

3 R. Klamut, Aktywność obywatelska jako rodzaj aktywności społecznej - perspektywa psychologiczna, „Studia Socjologiczne” 208/1 (2013).

${ }^{4}$ E. Aronson, T. Wilson, E. Akert, Psychologia społeczna- serce i umyst, Zysk i S-ka, Poznań 2007; B. Wojciszke, Człowiek wśród ludzi. Zarys psychologii społecznej, Scholar, Warszawa 2009.

5 M. Lewicka, Kup Pan ksiażkę... Mechanizmy aktywności obywatelskiej Polaków, „Studia Psychologiczne" 42/4 (2004); M. Lewicka, Dwuścieżkowy model aktywności społecznej: kapitat społeczny czy kulturowy?, [w:] Różne oblicza altruizmu, red. D. Rutkowska, A. Szuster, Scholar, Warszawa 2008; K. Skarżyńska, K. Henne, Studenci jako obywatele: kapitat ludzki i spoteczny jako źródła akceptacji porzqdku politycznego i ekonomicznego oraz aktywności społecznej, „Psychologia Społeczna” 21/7(2012); A.M. Omoto, M. Snyder, J.D. Hackett, Personality and Motivational Antecedents of Activism and Civic Engagement, „Journal of Personality” 78/6 (2010); A.M. Zalewska, B. Krzywosz-Rynkiewicz, Psychologiczne portrety młodych Polaków. Rozwojowe i podmiotowe uwarunkowania aktywności obywatelskiej młodzieży, Wydawnictwo SWPS, Warszawa 2011.

${ }^{6}$ K. Skarżyńska, Człowiek a polityka. Zarys psychologii politycznej, Scholar, Warszawa 2005.

${ }^{7}$ R. Klamut, op. cit. 
opisywaną aktywność lub sumę różnych działań nastawionych na interes społeczny. Coraz częściej dostrzega się jednak potrzebę uwzględniania zróżnicowania działań podejmowanych w ramach aktywności obywatelskiej ${ }^{8}$.

Każda aktywność człowieka jest efektem procesów motywacyjnych. W badaniach nad aktywnością obywatelską poszukuje się istotnych czynników motywacyjnych i uwarunkowań osobowościowych, od których zależy poziom i charakter (specyfika) tego rodzaju działalności obywateli, tak istotnego w kontekście jakości funkcjonowania społeczeństwa demokratycznego. W poszukiwaniu źródeł motywacji warto sięgnąc także do czynników podstawowych. Takim podstawowym czynnikiem uaktywniającym działanie człowieka jest bezpieczeństwo.

\subsection{Bezpieczeństwo - podstawa do działania}

Bezpieczeństwo stanowi przedmiot badań $w$ wielu dziedzinach naukowych opisujących funkcjonowanie człowieka. Jest uwzględniane w badaniach socjologicznych, politologicznych, ekonomicznych, a także w psychologii - w kontekście uwarunkowań ludzkiej aktywności ${ }^{9}$.

Kategoria ta jest przedstawiana $\mathrm{w}$ perspektywie obiektywnej lub subiektywnej. W perspektywie obiektywnej, mówiąc o bezpieczeństwie, przedstawiciele różnych dziedzin naukowych koncentrują się na zewnętrznych warunkach życia człowieka, mających wpływ na jego jakość oraz różnego rodzaju zagrożeniach czyhających na człowieka. Zagrożenia te mogą mieć różnorodne źródła. Można wskazać na źródła ekonomiczne, społeczne, kulturowe, cywilizacyjne, środowiskowe, polityczne ${ }^{10}$.

Problem bezpieczeństwa jednakże nie może być analizowany jedynie w terminach politycznych, socjologicznych, ekonomicznych warunków, ale powinien być także opisywany jako psychologiczny fenomen ${ }^{11}$. Jedna $\mathrm{z}$ podstawowych prawidłowości psychologicznych wskazuje, że człowiek subiektywnie rozumie świat, w którym żyje, i podejmuje określone działania nie tyle $\mathrm{w}$ zgodzie $\mathrm{z}$ obiektywnymi uwarunkowaniami, ale zgodnie z subiektywnym obrazem sytuacji, w której się znajduje ${ }^{12}$. Także bezpieczeństwo jest przeżywane subiektywnie $\mathrm{i}$ to jest właściwa perspektywa psychologiczna. $\mathrm{Na}$ potrzebę uwzględniania analiz psychologicznych w kwestii bezpieczeństwa zwraca uwagę Daniel Bar-Tal, który od lat analizuje problematykę konfliktu izraelsko-palestyńskiego i

\footnotetext{
${ }^{8}$ M. Lewicka, Kup Pan ksiqżkę...; K. Skarżyńska, K. Henne, op. cit.

${ }^{9}$ D. Bar-Tal, Contents and origins of the Israelis' beliefs about security, „International Journal of Group Tensions" 1991/21; D. Bar-Tal, D. Jacobson, A Psychological Perspective on Security, „Applied Psychology: An International Review” 47/1 (1998); R. Klamut, Bezpieczeństwo jako pojęcie psychologiczne, „Zeszyty Naukowe Politechniki Rzeszowskiej: Ekonomia i Nauki Humanistyczne” 19/4 (2012); A. Maslow, Motywacja i osobowość, PAX, Warszawa 1990.

10 D. Jacobson, D. Bar-Tal, Structure of Security Beliefs among Israeli Students, „Political Psychology" 16/3 (1995); L. Korzeniowski, Zarzqdzanie bezpieczeństwem. Rynek, ryzyko, zagrożenie, ochrona, [w:] Zarzqdzanie bezpieczeństwem, red. P. Tyrała, PSB, Kraków 2000; M. Pomykała, Bezpieczeństwo - w poszukiwaniu definicji, „Zeszyty Naukowe Politechniki Rzeszowskiej: Zarządzanie i Marketing” 2010/17.

${ }^{11}$ D. Bar-Tal, Contents and origins of the Israelis' beliefs...

${ }^{12}$ T. Maruszewski, Psychologia poznania, Gdańskie Wydawnictwo Psychologiczne, Gdańsk 2001; E. Nęcka, J. Orzechowski, B. Szymura, Psychologia poznawcza, PWN, Warszawa 2006.
} 
poszukuje sposobów jego rozwiązania ${ }^{13}$. Wskazuje, że zrozumienie kwestii bezpieczeństwa wymaga również analizy psychologicznej, bezpieczeństwo nie istnieje bowiem w oderwaniu od percepcji jednostki. Ludzie postrzegają zdarzenia i warunki zewnętrzne, oceniają je, a następnie tworzą przekonania na temat stanu bezpieczeństwa. Określanie stanu bezpieczeństwa jest zatem oparte na procesach poznawczych ${ }^{14}$.

Bezpieczeństwo jest jedną z podstawowych kategorii motywacyjnych. Traktowane jest jako czynnik istotny dla właściwego funkcjonowania, niezbędne do podejmowania aktywności ważnych dla jednostki. Najczęściej jest opisywane w ramach podstawowych czynników motywacyjnych - potrzeb i wartości, lecz także jako poczucie lub przekonanie $^{15}$.

Bezpieczeństwo jest rozumiane jako podstawowa potrzeba człowieka i odgrywa ogromną rolę $w$ wartościowaniu otoczenia oraz podejmowaniu działań ${ }^{16}$. Abraham Maslow pisze o kategorii potrzeb bezpieczeństwa, których zaspokojenie jest niezbędne do zdrowego funkcjonowania człowieka. Poziom odczuwania zależy od uwarunkowań środowiskowych i okoliczności, ale także od psychologicznej struktury jednostki. Niezaspokojenie potrzeb, również potrzeb bezpieczeństwa, powoduje napięcie wewnętrzne uruchamiające aktywność nastawioną na redukcję tego napięcia ${ }^{17}$.

Bezpieczeństwo rozumiane jako wartości w inny sposób motywuje człowieka do działania. Nie jako brak, który domaga się zaspokojenia, ale jako punkt odniesienia dla planowanych w przyszłości działań. Wartości rozumiane są jako przekonania, które dotyczą pożądanych celów, jakie sobie stawiają ludzie, stanowią kategorie ponadsytuacyjne, bardziej ogólne i o względnie stałym charakterze. Nasycone są emocjami, dzięki czemu zawierają w sobie również motywację do działania ${ }^{18}$. Bezpieczeństwo jako wartość stanowi szerszą kategorię ogniskującą podejmowanie aktywności nastawionej na bezpieczeństwo rodziny, bezpieczeństwo narodowe, ład (porządek) społeczny, czystość, odwzajemnianie przysług ${ }^{19}$.

Pojęciem, które może stanowić kryterium do oceny poziomu odczuwania psychologicznie rozumianego bezpieczeństwa, może być poczucie bezpieczeństwa. Poczucie jest efektem zaspokajania potrzeby i realizacji wartości. Potrzeba i wartości to

${ }^{13}$ D. Bar-Tal, Israel-Palestinian conflict: A cognitive analysis, ,International Journal of Intercultural Relations” 1990/14; D. Bar-Tal, Contents and origins...; D. Bar-Tal, D. Jacobson, op. cit.; D. BarTal, T. Magal, E. Halperin, The paradox of security views in Israel. A social-psychological explanation, [w:] Existential threats and civil-security relations, red. O. Barak, G. Sheffer, Lexington Books, Lanham 2009.

${ }^{14}$ D. Bar-Tal, D. Jacobson, op. cit.

${ }^{15}$ D. Bar-Tal, Contents and origins...; D. Bar-Tal, D. Jacobson, op. cit.; D. Jacobson, D. Bar-Tal, Structure of Security Beliefs among Israeli Students, „Political Psychology” 16/3 (1995); A. Maslow, op. cit.; L. Korzeniowski, Potrzeby i wartości a poczucie bezpieczeństwa menedżerów, „Acta Universitatis Wratislaviensis. Socjologia” 2006; S.H. Schwartz, A Proposal for Measuring Value Orientations across Nations. Chapter 7 in the Questionnaire Development Package of the European Social Survey, 2003.

${ }^{16}$ A. Bańka, Społeczna psychologia środowiskowa, Scholar, Warszawa 2002.

${ }^{17}$ A. Maslow, op. cit.

${ }^{18}$ P. Brzozowski, Uniwersalność struktury wartości: Koncepcja Shaloma H. Schwartza, „Roczniki psychologiczne” 2002/5; J. Cieciuch, Nadzieja jako moderator zwiazku poczucia koherencji z preferencjami wartości, „Fides et ratio” 2010/2.

${ }^{19}$ S.H. Schwartz, op. cit. 
pojęcia związane z dynamika, działaniem, poczucie zaś odnosi się do stanu odczuwania, doświadczania. To stan przeżywania satysfakcji, zadowolenia wynikającego z posiadania określonego (wystarczającego z punktu widzenia jednostki) poziomu bezpieczeństwa ${ }^{20}$. Bar-Tal wskazuje zaś, że poczucie bezpieczeństwa (lub zagrożenia) jest częścią osobistego repertuaru poznawczo-afektywnego i wyraża się $\mathrm{w}$ przekonaniach ${ }^{21}$. Te przekonania w efekcie mają emocjonalne i behawioralne implikacje: wzbudzają reakcje emocjonalne $i$ ukierunkowuja intencje na działania ${ }^{22}$. Przekonania dotyczace bezpieczeństwa mają taki sam charakter jak inne przekonania. Mają naturę subiektywną, zależą od posiadanej wiedzy i psychologicznych dyspozycji osób, które różnie spostrzegają swoje otoczenie i różnicują informacje, a w efekcie interpretują je w określony sposób. Istotny jest także kontekst społeczny: w tworzeniu przekonań ma znaczenie proces socjalizacji i uwarunkowania życia ludzi jako członków grup. Te przekonania są częścią wiedzy społecznej jednostki - stworzonych reprezentacji poznawczych dotyczących zależności społecznych. One kierują także społeczną aktywnością człowieka ${ }^{23}$.

Przedstawione charakterystyki bezpieczeństwa $\mathrm{w}$ kontekście psychologicznym uwidaczniają jego zróżnicowanie. Wskazane kategorie opisu można odnieść do podstawowych aspektów ludzkiego funkcjonowania - emocjonalności i racjonalności oraz uwzględnić je w doświadczaniu bezpieczeństwa przez konkretnego człowieka. Taki sposób rozumienia bezpieczeństwa daje możliwość wyróżnienia w jego charakterystyce dwóch aspektów: stanu odczuwania oraz refleksji nad bezpieczeństwem swoim, bliskich i szerszego otoczenia, a także rozumienia jego ważności. Pierwszy aspekt ma charakter emocjonalny i może być określony jako poczucie, drugi ma charakter poznawczy i może być opisany jako refleksja (nad bezpieczeństwem) ${ }^{24}$.

Obecnie bezpieczeństwo jest najczęściej opisywane i badane jako jedna $\mathrm{z}$ wartości $\mathrm{w}$ koncepcji Shaloma Schwartza. Interesujący jest jednak także, pod względem istoty doświadczania bezpieczeństwa, kontekst: emocje-racjonalność.

\subsection{Aktywność obywatelska a doświadczanie bezpieczeństwa}

Każda z przedstawionych kategorii psychologicznego rozumienia bezpieczeństwa jest powiązana z ogólną aktywnością człowieka. Istnieją także badania wskazujące na istnienie zależności między doświadczaniem bezpieczeństwa a szeroko rozumianą aktywnością obywatelską lub pozwalające zakładać istnienie takich zależności. Bezpieczeństwo jako wartość było badane w kontekście preferencji politycznych oraz aktywności obywatelskiej. Badanie przeprowadzone przez Schwartza i współpracowników pokazuje, że bezpieczeństwo jest jedną z kategorii wartości, których uwzględnianie ma znaczenie $\mathrm{w}$ głosowaniu na partie centrowo-prawicowe $\mathrm{w}$ porównaniu z partiami centrowo-lewicowymi podczas wyborów parlamentarnych we Włoszech ${ }^{25}$. W badaniach European Social Survey (ESS) wyniki pokazują, że bezpieczeństwo jako

${ }^{20}$ R. Klamut, Bezpieczeństwo jako pojęcie...

${ }^{21}$ D. Bar-Tal, Contents and origins ...

${ }^{22}$ D. Jacobson, D. Bar-Tal, Structure of Security Beliefs...

${ }^{23}$ D. Bar-Tal, D. Jacobson, A Psychological Perspective...

${ }^{24}$ R. Klamut, Bezpieczeństwo jako pojęcie...

${ }^{25}$ G.V. Caprara, S. Schwartz, C. Capanna, M. Vecchione, C. Barbaranelli, Personality and politics: Values, traits, and political choice, „Political Psychology” 2006/27. 
kategoria wartości jest predyktorem ogólnego poziomu aktywności obywatelskiej w trzech z dwudziestu sześciu badanych krajów Europy. W Finlandii i Hiszpanii zależność jest dodatnia (bezpieczeństwo zwiększa zaangażowanie w aktywność obywatelska), w Holandii zaś zależność jest ujemna (bezpieczeństwo zmniejsza poziom zaangażowania) ${ }^{26}$.

Inne badania bezpieczeństwa ukazujące jego znaczenie w kontekście aktywności społecznej pokazują, że przekonania dotyczące bezpieczeństwa kierują społeczną aktywnością człowieka. Badania Bar-Tala i Dana Jacobsona dają podstawę do poszukiwania zależności pomiędzy emocjonalnym i poznawczym aspektem doświadczania bezpieczeństwa a aktywnością nastawioną na interes społeczny ${ }^{27}$.

W badaniu zależności doświadczanie bezpieczeństwa - aktywność obywatelska interesujące wydaje się uwzględnienie zmiennej płci. Znaczenie płci w kontekście podejmowania aktywności obywatelskiej nie jest jednoznacznie określone. Maria Lewicka przytacza dane wskazujące, że to mężczyźni charakteryzują się wyższym poziomem ogólnej aktywności ${ }^{28}$. Również badania ESS analizowane przez Justynę Nyćkowiak przynoszą dane wskazujące na wyższy poziom zaangażowania w aktywność polityczną $\mathrm{w}$ grupie mężczyzn $\mathrm{w}$ dwudziestu na dwadzieścia dwa kraje, największe różnice widoczne są w Polsce ${ }^{29}$. Jednakże wyniki ESS analizowane przez Piotra Radkiewicza i Krystynę Skarżyńską wskazują, że płeć nie stanowiła istotnego predyktora ogólnego poziomu aktywności nastawionej na interes społeczny ${ }^{30}$.

Płeć może mieć także znaczenie w kontekście przeżywania różnych aspektów bezpieczeństwa. Badania Jacobsona i Bar-Tala $^{31}$ wskazują, że w zakresie ogólnego poziomu bezpieczeństwa mieszkańców Izraela (rejonu świata zmagającego się ciągle z problemem wojny) kobiety doświadczają większym stopniu niż mężczyźni odczuć negatywnych wskazujących na poczucie zagrożenia. Dodatkowo, podawanie w badaniach informacji o atakach terrorystycznych i wojnie w Zatoce Perskiej obniżało poczucie bezpieczeństwa u kobiet, mężczyźni zaś opisywali podawane fakty w większym stopniu jako zdarzenia pojawiające się w świecie, bez zaangażowania emocjonalnego w zakresie doświadczania bezpieczeństwa. W odniesieniu do aktualnej sytuacji emocje związane z poczuciem bezpieczeństwa mają większe znaczenie u kobiet niż u mężczyzn, to one w większym stopniu uwzględniają aspekt emocjonalny w ocenie sytuacji. Mężczyźni uruchamiają wówczas w większym stopniu analizę poznawczą.

\subsection{Pytania badawcze i hipotezy}

$\mathrm{W}$ prowadzonych badaniach sformułowano następujące pytania badawcze:

1. Czy istnieje zależność pomiędzy badanymi aspektami doświadczanego bezpieczeństwa (poczucie i refleksja) a różnymi rodzajami aktywności obywatelskiej (społecznikostwo, partycypacja społeczna, indywidualna aktywność polityczna, partycypacja polityczna) i jak wygląda jej zróżnicowanie?

26 P. Radkiewicz, K. Skarżyńska, Dobro bliskich czy ogótu? Dobroć i uniwersalizm jako determinanty aktywności obywatelskiej $w$ Polsce $i$ innych krajach Europy, „Studia Psychologiczne" 44/3 (2006).

${ }^{27}$ D. Bar-Tal, D. Jacobson, A Psychological Perspective...

${ }^{28}$ M. Lewicka, Kup Pan ksiażkę...

29 J. Nyćkowiak, Political Activity: Is Trust in Democratic Institutions Really a Relevant Determinant?, ,International Journal of Sociology” 39/1 (2009).

${ }^{30}$ P. Radkiewicz, K. Skarżyńska, op. cit.

${ }^{31}$ D. Jacobson, D. Bar-Tal, Structure of Security Beliefs... 
2. Co ma większe znaczenie w podejmowaniu określonych rodzajów aktywności obywatelskiej - poczucie czy refleksja?

3. Jaką rolę w badanych zależnościach zajmuje płeć?

Do weryfikacji przyjęto trzy hipotezy:

H1. Doświadczanie bezpieczeństwa ma większe znaczenie w aktywnościach indywidualnych (Społecznikostwo i Indywidualna aktywność obywatelska), niż w aktywnościach wspólnotowych (Partycypacja społeczna i Partycypacja polityczna).

H2. Większe znaczenie w podejmowaniu aktywności obywatelskiej odgrywa poczucie bezpieczeństwa niż refleksja nad nim.

H3. Płeć różnicuje zależność doświadczanie bezpieczeństwa - u kobiet większe znaczenie w zaangażowaniu się w aktywność obywatelską odgrywa aspekt emocjonalny (poczucie), dla mężczyzn zaś - aspekt poznawczy (refleksja).

\section{METODA}

\subsection{Osoby badane}

Badania przeprowadzono na grupie studentów studiów stacjonarnych i niestacjonarnych oraz dorosłych niestudiujących z terenu Podkarpacia (314 osób). Wiek badanych mieścił się w granicach 19-84 lat, średnia wieku to 33,3 roku, przy zmienności określonej za pomocą odchylenia standardowego $\mathrm{SD}=12,9$ roku. W grupie są 183 kobiety i 131 mężczyzn; większość osób badanych (172) mieszka w mieście, reszta na wsi. W całej badanej grupie 146 osób posiada rodziny, reszta jest stanu wolnego.

\subsection{Narzędzia badawcze}

W badaniach wykorzystano dwa autorskie kwestionariusze samoopisowe. Kwestionariusz Aktywności Obywatelskiej (KAO) został skonstruowany na podstawie modelu teoretycznego Klamuta ${ }^{32}$ i pozwala określić poziom zaangażowania w cztery rodzaje aktywności: Społecznikostwo (SP), Partycypację społeczną (PS), Indywidualną aktywność polityczną (IAP) oraz Partycypację polityczną (PP). Kwestionariusz składa się z 17 twierdzeń z pięciopunktową skalą odpowiedzi, w której 1 oznacza ,zdecydowanie nie”, 5 zaś - „zdecydowanie tak”. Przykładowe stwierdzenia to: „Zdarza mi się poświęcać czas na pomoc osobom spoza rodziny lub grona znajomych (np. robiąc zakupy, pomagając w nauce)” (SP); „Uczestniczę aktywnie w działaniach stowarzyszenia, fundacji czy grupy przy parafii” (PS); ,Świadomie wybieram swojego kandydata w wyborach parlamentarnych, analizując różne dostępne informacje” (IAP); „Organizacja polityczna jest miejscem mojego zaangażowania w działania na rzecz innych” (PP). W badaniach weryfikacyjnych publikowanych $w$ innym miejscu ${ }^{33}$ rzetelność badanych skal liczona za pomocą współczynnika Alfa Cronbacha wynosiła: $\mathrm{SP}=0,76$; $\mathrm{PS}=0,76$; IAP = 0,77 oraz dla $\mathrm{PP}=0,82$. Analiza konfirmacyjna potwierdziła zakładany czteroczynnikowy model jako zadowalająco dopasowany do danych $\left(\mathrm{chi}^{2}=142,61\right.$; $\mathrm{df}=113$; $\mathrm{p}<0,05$; RMSEA = 0,036; GFI = 0,92; CFI = 0,87; SRMR = 0,067).

Skala Doświadczanego Bezpieczeństwa (SDB). Skala odnosi się do perspektywy doświadczania własnego bezpieczeństwa w aspektach emocjonalnym oraz poznawczym i

${ }^{32}$ R. Klamut, Aktywność obywatelska jako rodzaj...

${ }^{33}$ R. Klamut, Kwestionariusz Aktywności Obywatelskiej - narzędzie do badania różnych rodzajów aktywności obywatelskiej, „Psychologia Społeczna” (2015, w druku). 
służy do badania poziomu poczucia oraz refleksji nad bezpieczeństwem własnym i najbliższych ${ }^{34}$. Składa się z ośmiu twierdzeń ocenianych na skali pięciostopniowej (1 oznacza ,zdecydowanie nie”, 5 zaś - ,zdecydowanie tak”), z których trzy odnoszą się do oszacowania poziomu poczucia (przykładowe twierdzenia: „Aktualnie czuję, że mam zaspokojone podstawowe potrzeby dające mi przekonanie o bezpieczeństwie”; „W aktualnej rzeczywistości czuję się bezpiecznie"; w prezentowanym badaniu Alfa Cronbacha wynosi 0,74 ), a pięć odnosiło się do refleksji nad bezpieczeństwem własnym i najbliższych (przykładowe twierdzenia: „Często myślę o bezpieczeństwie mojej rodzin”y; „Często martwię się o przyszłość własną i moich najbliższych"; w prezentowanym badaniu Alfa Cronbacha wynosi 0,74).

\section{WYNIKI}

\subsection{Podstawowe statystyki i korelacje}

W zastosowanej procedurze badawczej najpierw obliczono średnie i odchylenia standardowe poszczególnych badanych zmiennych pozwalające oszacować ogólny poziom badanych zmiennych. Uzyskane wyniki przedstawiono w tabeli 1 .

Tabela 1. Parametry opisowe (średnia i odchylenie standardowe) oraz korelacje między rodzajami aktywności obywatelskiej i doświadczanego bezpieczeństwa

\begin{tabular}{|l|r|r|c|c|}
\hline Zmienne & $\mathbf{M}$ & SD & Poczucie & Refleksja \\
\hline SP & 3,28 & 0,73 & $-0,07$ & $0,21^{* *}$ \\
\hline PS & 2,40 & 0,78 & 0,09 & 0,08 \\
\hline IAP & 3,51 & 0,66 & $0,20^{* *}$ & $0,26^{* *}$ \\
\hline PP & 1,99 & 0,70 & $0,13^{*}$ & $-0,02$ \\
\cline { 1 - 2 } Poczucie & 3,51 & 0,75 & & \\
\cline { 1 - 2 } Refleksja & 4,16 & 0,53 & & \\
\cline { 1 - 2 } & & & &
\end{tabular}

SP - Społecznikostwo; PS - Partycypacja społeczna; IAP - Indywidualna aktywność polityczna; PP - Partycypacja polityczna

Doświadczanie bezpieczeństwa w obu aspektach osiąga wyższy poziom od średniej teoretycznej, w zakresie aktywności obywatelskiej wyższe wyniki charakteryzują aktywności indywidualne (SP i IAP), poniżej średniej teoretycznej kształtuje się poziom PS i najniżej - PP. W tabeli 1 przedstawiono także współczynniki korelacji między badanymi zmiennymi. Proste korelacje wskazują na istnienie zależności między poczuciem bezpieczeństwa a aktywnościami politycznymi, zarówno indywidualną (IAP), jak i wspólnotową (PP), oraz refleksją nad bezpieczeństwem a aktywnościami indywidualnymi - SP i IAP.

3.2. Znaczenie aspektów doświadczania bezpieczeństwa w wyjaśnianiu angażowania się w różne formy aktywności obywatelskiej

\footnotetext{
${ }^{34}$ R. Klamut, Bezpieczeństwo jako pojęcie...
} 
Za pomocą analizy regresji zbadano, czy wyróżnione aspekty doświadczania bezpieczeństwa stanowią predyktory podejmowania poszczególnych form aktywności obywatelskiej (tab. 2).

Tabela 2. Wyniki analizy regresji dla rodzajów aktywności obywatelskiej i doświadczanego bezpieczeństwa; regresja liniowa, metoda wprowadzania

\begin{tabular}{|c|c|c|c|c|c|}
\hline $\begin{array}{l}\text { Wymiar } \\
\text { wyjaśniany }\end{array}$ & $\begin{array}{l}\text { Kategorie } \\
\text { wyjaśniające }\end{array}$ & BETA & $\mathbf{t}$ & $\mathbf{p}$ & $\begin{array}{l}\text { Parametry } \\
\text { modelu }\end{array}$ \\
\hline \multirow[t]{2}{*}{ SP } & Poczucie & $-0,11$ & $-1,95$ & 0,05 & \multirow{2}{*}{$\begin{array}{l}\mathrm{R}_{\text {skor }}^{2}=0,05 \\
\mathrm{~F}(2,311)=9,27 \\
\mathrm{p}<0,001\end{array}$} \\
\hline & Refleksja & 0,23 & 4,10 & 0,001 & \\
\hline \multirow[t]{2}{*}{ IAP } & Poczucie & 0,17 & 3,04 & 0,01 & \multirow{2}{*}{$\begin{array}{l}\mathrm{R}_{\text {skor }}^{2}=0,09 \\
\mathrm{~F}(2,311)=15,78 \\
\mathrm{p}<0,001\end{array}$} \\
\hline & Refleksja & 0,23 & 4,17 & 0,001 & \\
\hline \multirow[t]{2}{*}{$\mathbf{P P}$} & Poczucie & 0,14 & 2,42 & 0,01 & \multirow{2}{*}{$\begin{array}{l}\mathrm{R}_{\text {skor }}^{2}=0,01 \\
\mathrm{~F}(2,311)=3,02 \\
\mathrm{p}=0,05\end{array}$} \\
\hline & Refleksja & $-0,05$ & $-0,79$ & 0,42 (ni) & \\
\hline
\end{tabular}

SP - Społecznikostwo; IAP - Indywidualna aktywność polityczna; PP - Partycypacja polityczna

W tabeli podano wyniki dla tych form aktywności, dla których zależności okazały się istotne, stąd brak Partycypacji społecznej. Uzyskane wyniki wskazują na istotne znaczenie obu aspektów doświadczania bezpieczeństwa w podejmowaniu aktywności obywatelskiej. Odgrywają one rolę w podejmowaniu trzech $\mathrm{z}$ czterech badanych rodzajów aktywności obywatelskiej. Wyjaśniają jednak niewielki poziom zmienności. Najmocniej związane są z IAP (wyjaśniają 9\% zmienności wyników w tym rodzaju aktywności), w mniejszym stopniu wyjaśniają zmienność wyników w drugim z rodzajów indywidualnej aktywności SP (5\%), a najsłabiej zaś, bo jedynie w $1 \%$, w PP.

Poczucie bezpieczeństwa jest predyktorem każdej z form aktywności obywatelskiej powiązanych z doświadczeniem bezpieczeństwa, a w wyjaśnianiu SP i IAP znaczenie ma także aspekt refleksji nad bezpieczeństwem. W tych formach aktywności, w których predyktorami są oba aspekty doświadczania bezpieczeństwa, istotniejszą rolę odgrywa refleksja - współczynniki określające siłę związku refleksji z każdym z dwóch rodzajów aktywności wynoszą $\beta=0,23$, poczucia zaś z IAP $\beta=0,17$ oraz poczucia ze SP $\beta=-$ 0,11 . Ten ostatni wynik jest dodatkowo interesujący, zależność jest bowiem ujemna - to obniżenie poczucia bezpieczeństwa zwiększa działania nastawione na rzecz innych osób potrzebujących pomocy. Pozostałe zależności są pozytywne, można więc wskazać, że wzrost poczucia i refleksji nad bezpieczeństwem zwiększa poziom zaangażowania w aktywności powiązane $\mathrm{z}$ bezpieczeństwem.

\subsection{Płeć jako czynnik różnicujący zależność doświadczanie bezpieczeństwa - aktywność obywatelska}

W dalszej części analiz statystycznych sprawdzona została także rola płci jako zmiennej pośredniczącej w analizowanej podstawowej zależności bezpieczeństwo aktywność obywatelska. Uzyskane wyniki uwzględniające porównanie analiz regresji dla porównywanych grup płciowych przedstawiono w tabeli 3. 
Tabela 3. Wyniki analizy regresji dla rodzajów aktywności obywatelskiej i doświadczanego bezpieczeństwa $\mathrm{z}$ uwzględnieniem porównań grup kobiet i mężczyzn; regresja liniowa, metoda wprowadzania

\begin{tabular}{|c|c|c|c|c|c|c|c|c|c|}
\hline \multirow{2}{*}{$\begin{array}{l}\text { Wymiar } \\
\text { wyjaśnia } \\
\text {-ny }\end{array}$} & \multirow{2}{*}{$\begin{array}{l}\text { Kategorie } \\
\text { wyjaśnia- } \\
\text { jące }\end{array}$} & \multicolumn{4}{|c|}{$\mathbf{K}$} & \multicolumn{4}{|c|}{ M } \\
\hline & & BETA & $\mathbf{t}$ & p & $\begin{array}{l}\text { Parametry } \\
\text { modelu }\end{array}$ & BETA & $\mathbf{t}$ & p & $\begin{array}{l}\text { Parametry } \\
\text { modelu }\end{array}$ \\
\hline \multirow[t]{2}{*}{ SP } & Poczucie & $-0,07$ & $-0,89$ & 0,38 & \multirow{2}{*}{$\begin{array}{l}\mathrm{R}_{\text {skor }}^{2}=0,04 \\
\mathrm{~F}(2,180)=4,94 \\
\mathrm{p}<0,01\end{array}$} & $-0,17$ & $-1,92$ & $0,06^{\#}$ & \multirow{2}{*}{$\begin{array}{l}\mathrm{R}_{\text {skor }}^{2}=0,05 \\
\mathrm{~F}(2,128)=4,31 \\
\mathrm{p}<0,05\end{array}$} \\
\hline & Refleksja & 0,23 & 3,11 & 0,01 & & 0,22 & 2,54 & 0,05 & \\
\hline \multirow[t]{2}{*}{ IAP } & Poczucie & 0,30 & 4,26 & 0,001 & \multirow{2}{*}{$\begin{array}{l}\mathrm{R}_{\text {skor }}^{2}=0,12 \\
\mathrm{~F}(2,180)=12,96 \\
\mathrm{p}<0,001\end{array}$} & 0,01 & 0,01 & 0,93 & \multirow{2}{*}{$\begin{array}{l}\mathrm{R}_{\text {skor }}^{2}=0,12 \\
\mathrm{~F}(2,128)=9,46 \\
\mathrm{p}<0,001\end{array}$} \\
\hline & Refleksja & 0,15 & 2,16 & 0,05 & & 0,36 & 4,28 & 0,001 & \\
\hline \multirow[t]{2}{*}{$\mathbf{P P}$} & Poczucie & 0,21 & 2,81 & 0,01 & \multirow{2}{*}{$\begin{array}{l}\mathrm{R}_{\text {skor }}^{2}=0,03 \\
\mathrm{~F}(2,180)=3,97 \\
\mathrm{p}<0,05\end{array}$} & 0,06 & 0,61 & 0,54 & \multirow{2}{*}{$\begin{array}{l}\mathrm{R}_{\text {skor }}^{2}=0,007 \\
\mathrm{~F}(2,128)=0,54 \\
\mathrm{p}=0,59 \text { (ni) }\end{array}$} \\
\hline & Refleksja & $-0,02$ & $-0,28$ & 0,78 & & $-0,08$ & $-0,93$ & 0,35 & \\
\hline
\end{tabular}

K - kobiety; M - mężczyźni; SP - Społecznikostwo; IAP - Indywidualna aktywność polityczna; PP - Partycypacja polityczna

Wyniki wskazują, że najbardziej istotne różnice między kobietami i mężczyznami dotyczą IAP. W obu grupach płciowych doświadczanie bezpieczeństwa wyjaśnia około $12 \%$ zmienności w zakresie IAP, lecz znaczenie poszczególnych aspektów bezpieczeństwa jest różne. Oba aspekty doświadczania bezpieczeństwa są predyktorami tej formy aktywności u kobiet, lecz większe znaczenie odgrywa poczucie $(\beta=0,30)$, w grupie mężczyzn zaś znaczenie odgrywa tylko refleksja $(\beta=0,36)$. Społecznikostwo jest wyjaśniane u obu płci przez refleksję nad bezpieczeństwem w podobnym stopniu ( $\beta=$ 0,23 u kobiet i $\beta=0,22$ u mężczyzn). Dodatkowo u mężczyzn pewne znaczenie (na poziomie trendu: $\mathrm{p}<0,06)$ odgrywa poczucie bezpieczeństwa. Zależność między poczuciem bezpieczeństwa a SP u mężczyzn jest ujemna $(\beta=-0,17)$, a więc to pogorszenie stanu emocjonalnego w kontekście przeżywania bezpieczeństwa podnosi poziom zaangażowania $\mathrm{w}$ aktywność na rzecz potrzebujących. Zależność między bezpieczeństwem a PP jest widoczna tylko u kobiet i dotyczy poczucia bezpieczeństwa ( $\beta$ $=0,21)$. Można więc wskazać, że wzrost poczucia bezpieczeństwa wiąże się ze wzrostem zaangażowania w społeczną aktywność polityczną kobiet. Aspekt emocjonalny bezpieczeństwa wyjaśnia jednak tylko 3\% zmienności w zakresie tego rodzaju aktywności obywatelskiej.

\section{DYSKUSJA}

W prezentowanym artykule zanalizowano zależności między doświadczaniem bezpieczeństwa i podejmowaniem różnych rodzajów aktywności obywatelskiej. Uzyskane wyniki dotyczące doświadczania bezpieczeństwa wskazują najpierw, że wyróżnienie odrębnych aspektów przeżywania bezpieczeństwa było zasadne. Opisują one różne zjawiska, ich interkorelacja wynosi $\mathrm{r}=0,16$; $\mathrm{p}<0,05$. Wyniki wskazują na posiadanie przez badanych poczucia bezpieczeństwa i wysokiego poziomu refleksji nad bezpieczeństwem swoim i bliskich, co świadczy o pozytywnym emocjonalnym odniesieniu do bezpieczeństwa, a jednocześnie o rozumieniu ważności tej kategorii 
doświadczeń. Natomiast wyniki dotyczące aktywności obywatelskiej są odzwierciedleniem istniejącego zaangażowania Polaków w działania na rzecz interesu społecznego. Najwyższy poziom charakteryzuje zaangażowanie w indywidualne działania na rzecz zmiany politycznego status quo: od zabierania głosu w ważnych społecznie sprawach do podpisywania petycji czy demonstrowania. Również stosunkowo wysoko plasuje się angażowanie się w pomoc osobom potrzebującym. Aktywności wspólnotowe wymagają już dodatkowych czynników motywacyjnych, stąd wyniki wskazują na niski (PS) i bardzo niski (PP) ich poziom. Polska ma bardzo niski poziom aktywności obywatelskiej w porównaniu z krajami Europy, zwłaszcza jeśli chodzi o zaangażowanie wspólnotowe $\mathrm{e}^{35}$ - aktualne badania to potwierdzają.

Uzyskane wyniki pozwalają potwierdzić hipotezę H1. Bezpieczeństwo ma znaczenie zdecydowanie mocniejsze w tych formach aktywności nastawionych na interes społeczny, które są podejmowane indywidualnie, jedynie u kobiet aspekt emocjonalny odgrywa niewielkie znaczenie także w zakresie PP. Doświadczanie bezpieczeństwa to doświadczenie indywidualne. Subiektywnie tworzone odniesienie do rzeczywistości skutkuje podejmowaniem działań indywidualnych zarówno w obszarze służby, jak i władzy. Wydaje się, że motywacja związana z doświadczaniem bezpieczeństwa dotyczy funkcjonowania jednostkowego i nie uwzględnia kontekstu społecznego. Nie ma więc znaczenia jako czynnik motywujący do aktywności realizowanej wspólnie. W takich warunkach większe znaczenie powinny mieć motywy społeczne, nastawione na budowanie także pozytywnych relacji $\mathrm{z}$ innymi ${ }^{36}$.

Hipoteza H2 dotyczyła znaczenia obu aspektów doświadczania bezpieczeństwa w wyjaśnianiu podejmowania różnych form aktywności obywatelskiej. Zakładała, że to aspekt emocjonalny ma większe znaczenie. Uzyskane wyniki nie pozwalają jednoznacznie potwierdzić takiego założenia. Poczucie pojawia się jako czynnik wyjaśniający dla trzech z czterech rodzajów badanych aktywności, podczas gdy refleksja nad bezpieczeństwem dla dwóch, lecz to aspekt poznawczy jest mocniejszym predyktorem. Oba aspekty doświadczania bezpieczeństwa mają istotne znaczenie. Znaczenie aspektu emocjonalnego jako czynnika powodującego podejmowanie aktywności obywatelskiej, jak każdej aktywności, nie wydaje się zaskoczeniem. To on spełnia podstawową funkcję regulacyjną ${ }^{37}$. Interesująca jest rola aspektu poznawczego. Nie tylko emocje, ale także refleksja - dostrzeżenie wagi bezpieczeństwa własnego i bliskich, zastanawianie się nad tym problemem i troska o bezpieczeństwo - także motywują do działania takiego, które nastawione jest na poprawę jakości życia, a więc również podniesienia poczucia bezpieczeństwa. Uzyskane wyniki mogą dodatkowo wskazywać, że aktywność obywatelska jest aktywnością intencjonalną, a nie (tylko) nastawioną na obronę i uwzględniającą również poziom poznawczy, oprócz

\footnotetext{
${ }^{35}$ J. Nyćkowiak, op.cit.; P. Radkiewicz, K. Skarżyńska, Dobro bliskich czy ogótu...

${ }^{36}$ J. Grzelak, Czy stajemy się lepsi? O nieoczekiwanym uspotecznieniu Polaków, [w:] Jak Polacy przegrywaja? Jak Polacy wygrywajq?, red. M. Drogosz, Gdańskie Wydawnictwo Psychologiczne, Gdańsk 2005; J. Grzelak, I. Zinserling, Aktywność społeczna a wartości $i$ orientacje społeczne, „Studia Psychologiczne” 41/3 (2003).

37 S. Epstein, Cognitive-Experiential Self-Theory, [w:] Handbook of Personality: Theory and Research, red. L. Pervin, Guilford Press, New York 1990.
} 
doświadczeniowego/emocjonalnego, w podejmowaniu działań na rzecz interesu społecznego $^{38}$.

Uzyskane wyniki w dużej mierze potwierdzają hipotezę H3. Istotną zmienną różnicującą zależność: doświadczanie bezpieczeństwa - aktywność obywatelska jest płeć, chociaż znaczenie aspektów bezpieczeństwa w wyjaśnianiu aktywności obywatelskiej dla każdej z płci nie jest tak jednoznaczne, jak zakładano. Jest różne w zależności od płci, ale też w zależności od rodzaju aktywności. Dla kobiet poczucie bezpieczeństwa jest istotne jako predyktor aktywności politycznej - zarówno indywidualnej, jak i wspólnotowej. Znaczenie odgrywa również jednak refleksja - w działaniach indywidualnych zarówno nastawionych na służbę, jak i na władzę. Dla mężczyzn istotniejsze znaczenie ma rzeczywiście refleksja nad bezpieczeństwem, chociaż w indywidualnym zaangażowaniu pomocowym (SP) pomaga im także $w$ pewnym stopniu aspekt emocjonalny bezpieczeństwa, lecz w kontekście negatywnym (poczucie zagrożenia). Emocjonalne przeżywanie bezpieczeństwa jako czynnika motywacyjnego do podejmowania aktywności obywatelskiej charakteryzuje więc głównie kobiety. Posiadanie poczucia bezpieczeństwa, a więc przekonanie o właściwym funkcjonowaniu podstawowych spraw życiowych, pomaga, by zaangażować się $\mathrm{w}$ aktywność polityczną, ale działalność indywidualna jest podejmowana przy dostrzeżeniu ważności doświadczania bezpieczeństwa i troski o nie. To refleksja nad bezpieczeństwem swoim i innych jest potrzebna do zajęcia się osobami w potrzebie.

Zależności między badanymi zmiennymi występują na poziomie istotnym, lecz nie są zbyt wysokie. Można by więc postawić pytanie o to, czy kategoria bezpieczeństwa jest zbyt odległa, by motywować do aktywności obywatelskiej. Bezpieczeństwo jest ważnym czynnikiem motywacyjnym uruchamiającym działania nastawione na minimalizowanie poczucia zagrożenia. Wydaje się zaś, że aktywność obywatelska ma charakter w większym stopniu intencjonalny niż obronny i niekoniecznie służy wprost redukowaniu poczucia zagrożenia. To raczej podejmowanie określonego działania będące wynikiem analizy sytuacji ${ }^{39}$, stąd doświadczanie bezpieczeństwa jest zbyt podstawową kategorią motywacyjną, żeby ujawniać duże zależności, lecz istotne powiązania istnieją. Może więc warto uwzględniać te kategorię jako element w budowaniu bardziej złożonych układów zależności wyjaśniających podejmowanie aktywności na rzecz interesu społecznego.

Wydaje się, że warto byłoby uwzględniać kategorię bezpieczeństwa zwłaszcza w sytuacji pogorszenia warunków życia, gdy poziom doświadczanego bezpieczeństwa się zmniejsza. Stabilna sytuacja życiowa nie skłania do koncentrowania się na doświadczaniu bezpieczeństwa. Dla rozumienia znaczenia bezpieczeństwa jako czynnika wyjaśniającego zachowanie człowieka znaczący może być też fakt, że bezpieczeństwo pojawia się głównie w analizach psychologów izraelskich. Wydaje się, że w większym stopniu ma on znaczenie w warunkach zagrożeń niż pokoju.

\section{ZAKOŃCZENIE}

Zaprezentowane w artykule wyniki badań wskazują, że wyróżnione aspekty bezpieczeństwa okazały się kolejnym czynnikiem mającym znaczenie, chociaż niezbyt wielkie, w podejmowaniu aktywności na rzecz interesu społecznego. Doświadczanie

\footnotetext{
${ }^{38}$ S. Epstein, op.cit.

${ }^{39}$ R. Klamut, Aktywność obywatelska jako rodzaj...
} 
bezpieczeństwa ma charakter subiektywny i przejawia się w obu wyróżnionych aspektach jako czynnik wyjaśniający angażowanie się w aktywności podejmowane indywidualnie. Refleksja służy pełniejszemu rozpoznaniu sytuacji, aspekt emocjonalny mobilizuje do uruchomienia określonego, właściwego schematu postępowania.

Przeprowadzone badania mają swoje ograniczenia. Osobami badanymi byli mieszkańcy jednego regionu Polski - Podkarpacia. W celu weryfikacji uzyskanych wyników warto byłoby przeprowadzić badania także w innych regionach lub na próbie ogólnopolskiej. Zastrzeżenia może budzić także duża rozpiętość wieku osób badanych, w większości jednak były to osoby młode i w średnim wieku.

W dalszych badaniach interesujące wydaje się podjęcie badań uwzględniających doświadczanie bezpieczeństwa w kontekście dynamicznym. Doświadczanie bezpieczeństwa nie ma stałego charakteru. Obserwacja sytuacji społecznej oraz dane zawarte w raporcie Diagnoza społeczna $2013^{40}$ wskazują, że obniża się jakość życia Polaków. Wydaje się, że w okolicznościach obniżania się poczucia bezpieczeństwa może się ono stać bardziej znaczącym czynnikiem motywacyjnym w podejmowaniu działań nastawionych nie tylko na interes własny, ale także interes społeczny. Może się stać przyczyną protestów i zmian społecznych, co już można było zaobserwować choćby w okresie powstawania Solidarności i w czasie transformacji ustrojowej ${ }^{41}$. Taka sytuacja może się także wiązać $\mathrm{z}$ podniesieniem poziomu refleksji nad bezpieczeństwem, co zwiększy jeszcze siłę zaangażowania w aktywność protestacyjną. Większą wartość społeczną (i mniej społecznych kosztów) wydają się jednak mieć takie działania, które są nastawione na poszerzanie wspólnego dobra bez potrzeby reagowania na negatywne sytuacje społeczne.

\section{LITERATURA}

[1] Aronson E., Wilson T., Akert E., Psychologia społeczna- serce i umyst, Zysk i Ska, Poznań 2007.

[2] Bańka A., Społeczna psychologia środowiskowa, Scholar, Warszawa 2002.

[3] Bar-Tal D., Israel-Palestinian conflict: A cognitive analysis, „International Journal of Intercultural Relations" 1990/14.

[4] Bar-Tal D., Contents and origins of the Israelis' beliefs about security, „International Journal of Group Tensions” 1991/21.

[5] Bar-Tal D., Jacobson D., A Psychological Perspective on Security, „Applied Psychology: An International Review" 47/1 (1998).

[6] Bar-Tal D., Magal T., Halperin E., The paradox of security views in Israel. A social-psychological explanation, [w:] Existential threats and civil-security relations, red. O. Barak, G. Sheffer, Lexington Books, Lanham 2009.

${ }^{40}$ J. Czapiński, Indywidualna jakość i styl życia. Diagnoza Spoteczna 2013 Warunki i Jakość Życia Polaków - Raport, „Contemporary Economics” [Special issue] 2013/7; A. Sułek, Stan spoteczeństwa obywatelskiego. Doświadczenie, działania dla społeczności $i$ kompetencje obywatelskie. Diagnoza Spoteczna 2013 Warunki i Jakość Życia Polaków - Raport, "Contemporary Economics" [Special issue] 2013/7.

${ }^{41}$ I. Krzemiński, Spoteczeństwo obywatelskie i symbole wspólnoty, [w:] Jak Polacy przegrywaja? Jak Polacy wygrywaja?, red. M. Drogosz, Gdańskie Wydawnictwo Psychologiczne, Gdańsk 2005. 
[7] Brzozowski P., Uniwersalność struktury wartości: Koncepcja Shaloma H. Schwartza, „Roczniki Psychologiczne” 2002/5.

[8] Cieciuch J., Nadzieja jako moderator zwiazku poczucia koherencji z preferencjami wartości, „Fides et ratio” 2010/2.

[9] Czapiński J., Indywidualna jakość i styl życia. Diagnoza Społeczna 2013 Warunki i Jakość Życia Polaków - Raport, „Contemporary Economics” [Special issue] 2013/7.

[10] Caprara G.V., Schwartz S., Capanna C., Vecchione M., Barbaranelli C., Personality and politics: Values, traits, and political choice, „Political Psychology" 2006/27.

[11] Epstein S., Cognitive-Experiential Self-Theory, [w:] Handbook of Personality: Theory and Research, red. L. Pervin, Guilford Press, New York 1990.

[12] Grzelak J., Czy stajemy się lepsi? O nieoczekiwanym uspotecznieniu Polaków, [w:] Jak Polacy przegrywaja? Jak Polacy wygrywaja?, red. M. Drogosz, Gdańskie Wydawnictwo Psychologiczne, Gdańsk 2005.

[13] Grzelak J., Zinserling I., Aktywność społeczna a wartości i orientacje społeczne, „Studia Psychologiczne” 41/3 (2003).

[14] Jacobson D., Bar-Tal D., Structure of Security Beliefs among Israeli Students, „Political Psychology” 16/3 (1995).

[15] Klamut R., Bezpieczeństwo jako pojęcie psychologiczne, „Zeszyty Naukowe Politechniki Rzeszowskiej: Ekonomia i Nauki Humanistyczne" 19/4 (2012).

[16] Klamut R., Aktywność obywatelska jako rodzaj aktywności spotecznej perspektywa psychologiczna, ,Studia Socjologiczne” 208/1 (2013).

[17] Klamut R., Kwestionariusz Aktywności Obywatelskiej - narzędzie do badania różnych rodzajów aktywności obywatelskiej, „Psychologia Społeczna” (2015, w druku).

[18] Korzeniowski L., Zarzqdzanie bezpieczeństwem. Rynek, ryzyko, zagrożenie, ochrona, [w:] Zarzadzanie bezpieczeństwem, red. P. Tyrała, PSB, Kraków 2000.

[19] Korzeniowski L., Potrzeby i wartości a poczucie bezpieczeństwa menedżerów, „Acta Universitatis Wratislaviensis. Socjologia” 2006.

[20] Krzemiński I., Społeczeństwo obywatelskie i symbole wspólnoty, [w:] Jak Polacy przegrywaja? Jak Polacy wygrywaja?, red. M. Drogosz, Gdańskie Wydawnictwo Psychologiczne, Gdańsk 2005.

[21] Lewicka M., Kup Pan ksiażkę... Mechanizmy aktywności obywatelskiej Polaków, „Studia Psychologiczne” 42/4 (2004).

[22] Lewicka M., Dwuścieżkowy model aktywności społecznej: kapitat społeczny czy kulturowy?, [w:] Różne oblicza altruizmu, red. D. Rutkowska, A. Szuster, Scholar, Warszawa 2008.

[23] Maruszewski T., Psychologia poznania, Gdańskie Wydawnictwo Psychologiczne, Gdańsk 2001.

[24] Maslow A., Motywacja i osobowość, PAX, Warszawa 1990.

[25] Nęcka E., Orzechowski J., Szymura B., Psychologia poznawcza, PWN, Warszawa 2006.

[26] Nyćkowiak J., Political Activity: Is Trust in Democratic Institutions Really a Relevant Determinant?, „International Journal of Sociology”39/1 (2009). 
[27] Omoto A. M., Snyder M., Hackett J. D., Personality and Motivational Antecedents of Activism and Civic Engagement, „Journal of Personality” 78/6 (2010).

[28] Pomykała M., Bezpieczeństwo - w poszukiwaniu definicji, „Zeszyty Naukowe Politechniki Rzeszowskiej: Zarządzanie i Marketing" 2010/17.

[29] Radkiewicz P., Skarżyńska K., Dobro bliskich czy ogótu? Dobroć i uniwersalizm jako determinanty aktywności obywatelskiej w Polsce i innych krajach Europy, „Studia Psychologiczne” 44/3 (2006).

[30] Schwartz S.H., A Proposal for Measuring Value Orientations across Nations. Chapter 7 in the Questionnaire Development Package of the European Social Survey, 2003, www.Europeansocialsurvey.org.

[31] Skarżyńska K., Człowiek a polityka. Zarys psychologii politycznej, Scholar, Warszawa 2005.

[32] Sułek A., Stan społeczeństwa obywatelskiego. Doświadczenie, działania dla społeczności i kompetencje obywatelskie. Diagnoza Spoteczna 2013 Warunki $i$ Jakość Życia Polaków - Raport, „Contemporary Economics” [Special issue] 2013/7.

[33] Wojciszke B., Człowiek wśród ludzi. Zarys psychologii społecznej, Scholar, Warszawa 2009.

[34] Zalewska A.M., Krzywosz-Rynkiewicz B., Psychologiczne portrety młodych Polaków. Rozwojowe i podmiotowe uwarunkowania aktywności obywatelskiej młodzieży, Wydawnictwo SWPS, Warszawa 2011.

SECURITY EXPERIENCE AND CIVIC ACTIVITY IN THE CONTEXT OF SEX

Security is one of the main categories that allows the proper functioning of a man. It can be understood objectively and subjectively. In the paper we refer to the subjective, psychological aspect of security and assume that the experience of security influences human activity, in general, and thus also influences a specific action - oriented to public interest. This paper discusses the fundamental relationship between two variables experience of security and civic activity and poses a question about the nature of this relationship, also taking into account sex differences. Both variables are treated as complex phenomena. Security experience consists of the emotional aspect (sense of security) and cognitive one (reflection on security). Whereas, an active citizenship is characterized by four types of activities: social commitment, social participation, individual political activity and political participation. This model is based on two criteria: field of involvement and attitude of an individual towards a group. The study has been conducted on a group of 314 people using two measures: the Experienced Security Scale and the Civic Activity Questionnaire. The results indicate that the assumed relationship does exist (although is not strong) and actually relates to the activity being performed individually (not in community). Sex differences are an important factor modifying basic relationship in such way that in men reflection on security plays more important role as a predictor of civic activity, while in women both aspects of security are important: sense of security and reflection on it.

Keywords: types of civic activity, sense of security, reflection on security, sex differences.

DOI:10.7862/rz.2014.hss.57

Przesłano do redakcji: lipiec 2014

Przyjęto do druku: grudzień 2014 